\title{
EDITORIAL
}

\section{O novo normal, a desconstrução, a regra vigente}

A Revista Entre-Lugar apresenta seu segundo número de 2020, sua vigésima segunda edição. Nela observamos mais uma vez o papel fundamental das instituições públicas, como universidades, no processo de produção do conhecimento científico brasileiro. Nesse contexto é importante frisar: o ano de 2020 será relembrado pelo estado pandêmico, suas consequências sociais, mas, também, pelas políticas de cortes e contingenciamentos implementadas que ocasionaram perdas significativas de recursos destinados às instituições de ensino superior públicas, aos institutos de pesquisa e órgãos e agências reguladoras e de fiscalização.

No campo das humanidades, o qual a Geografia se encontra, registrou-se cortes de bolsas e a inexistência de editais para o desenvolvimento de projetos de pesquisa. Essa condição se deu nos âmbitos federal e estadual. O reflexo disso se dará em dois momentos: em curto prazo, o desestímulo de jovens a cursarem a pós-graduação; e, em longo prazo, a diminuição significativa da produção científica implicando negativamente no desenvolvimento de ciência e tecnologia - uma perda imensurável.

As duas principais agências públicas brasileiras de fomento à pós-graduação e à pesquisa, a CAPES e o CNPq, sofreram reestruturações em suas políticas de incentivo. Neste ano de 2020 o CNPq, ao tornar público a concessão de bolsas de iniciação científica para o calendário de 2021, anunciou que as Ciências Humanas não será prioridade, uma decisão obtusa que trará grandes reflexos no incentivo à pesquisa brasileira, essencialmente entre os jovens. A CAPES, por sua vez, não tem renovado as bolsas DS (Demanda Social) dos programas de pós-graduação. 
Observamos, portanto, que o quadro pandêmico instaurado e instalado trouxe consigo condições favoráveis e propícias ao esvaziamento dos debates e dos enfrentamentos que são essenciais para fazer frente ao novo normal - o desmonte. Mudanças, decisões por meio de portarias e decretos, sem um debate ampliado com a comunidade científica desconstruíram décadas de trabalho, foram, estão sendo, implementadas ações e decisões à revelia, muitas sem a concordância ou consenso. Cito a desconstrução do Qualis Periódicos e Qualis Livros, instrumentos que foram construídos a partir de debates acumulados durante, no mínimo, uma década e meia.

O Grupo de Trabalho do Fórum de Ciências Humanas, composto pelas áreas de Ciências Sociais, Sociais Aplicadas Letras, Linguística e Artes, denominado de CHSSALLA, vinculadas à CAPES, apontam que essas mudanças impactaram veementemente os periódicos científicos brasileiros, essencialmente aqueles vinculados aos programas de pós-graduação e/ou associações de pesquisa e de representação da Ciências Humanas. Nessa edição publicamos, na seção “Análise de Conjuntura”, o trabalho desenvolvido CHSSALLA.

Alguns podem se perguntar: Qual o motivo de tratar-se disso neste editorial? Explicamos: a desconstrução do Qualis alterará a lógica e a importância dos periódicos e do significado da publicação e da publicização do conhecimento oriundo dos programas de pós-graduação. Na Geografia, é dizer que isso será um fato que marcará um novo ciclo. Como as métricas e os fatores de impactos pensados e exigidos pouco se enquadram no campo das humanidades e estão muito distantes da realidade brasileira, especialmente na Geografia, serão pouquíssimos os periódicos cujo fator de impacto terá efetiva relevância. Sim, os indexadores continuarão a existir e terão sua importância, mas a lógica da publicação deverá ser revista, deverá ser outra. Caso contrário muitos periódicos irão sucumbir. O estudo do CHSSALLA evidencia: 
“...o impacto perverso do uso de indicadores que respondem à lógica das maiores bases de indexação, dominadas pela dinâmica das empresas internacionais do mercado editorial, e que resulta em critérios de inclusão seletiva, negativos à disseminação ampla da pesquisa científica.” (CHSSALLA, dezembro de 2020)

Sob essa ótica, entendemos que a Geografia, como no passado, terá um papel importante - afinal as discussões sobre as métricas de avaliação e sobre o Qualis sempre foram muito caras à comunidade geográfica. A manutenção e a insistência dos periódicos serão essenciais na nossa avaliação, e eles servirão ainda mais como lugares de oportunidades para que pesquisadores possam divulgar suas ideias e resultados de pesquisa. No cenário pouco fértil relatado, com parcos investimentos em pesquisa, ciência e tecnologia, a manutenção dos periódicos, com políticas de gratuidade e de acesso livre podem vir a ser, e devem ser, o lugar no qual as ideias e ideais possam ter condições de maturação e desenvolvimento. Isso nos parece inclusive uma tenência, uma precaução a ser construída coletivamente para a fim de evitar danos ainda maiores.

A ideia central deverá ser um contraponto à lógica da mercantilização hoje presente nos periódicos gestados e administrados por grandes plataformas de editoras, verdadeiras corporações, sua maioria em língua inglesa. A ideia de "publish or perish" deverá ser substituída por algo como "publique, é uma contribuição social importante". Esse deve ser o mote e a cultura que deve ser incentivada para que os periódicos da Geografia continuem a existir e possam dar continuidade ao papel relevante que desempenham.

Nesse contexto de lugar profícuo, o segundo número de 2020 da Revista EntreLugar apresenta aos seus leitores doze textos inéditos provindos de pesquisas e experiências de grupos de pesquisa realizadas em diversas partes do Brasil e do exterior.

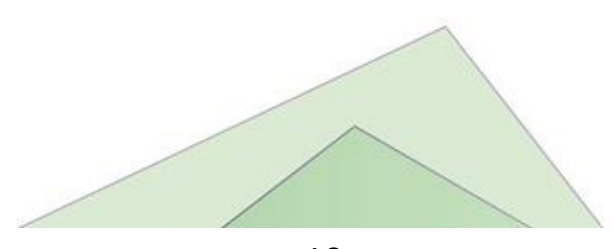


Manuscritos que versam sobre epistemologia da Geografia, estudos nos campos da Climatologia, Geografia Econômica, Políticas Públicas, Meio Ambiente e Vulnerabilidade, Gestão de Recursos Hídricos, Geografia e Ensino e Geografia Agrária. Temáticas que abordam a relação sociedade-natureza, a dinâmica rural-urbana, o clima e a sociedade, política e economia, todos trazendo consigo discussões críticas, o uso de técnicas e métodos, estudos de caso de grande valia para a ciência Geografia e suas áreas correlatas.

Soma-se a essa edição a resenha do livro "Os conceitos fundamentais da pesquisa sócio-espacial” do geógrafo Marcelo Lopes de Souza, e uma entrevista com Gilberto Fisch, docente da UNITAU, pesquisador do Instituto Nacional de Pesquisas Espaciais (INPE) e bolsista de produtividade em pesquisa do CNPq-Nível 1B. A entrevista contou com a colaboração do pesquisador Fabio de Oliveira Sanchez, da Universidade Federal de Juiz de Fora.

A capa é uma adaptação da obra “América Invertida”, do artista hispano-uruguaio Joaquín Torres García, criação de 1943. Que essa obra possa vir a ser uma inspiração para todos, que sua essência e seu significado nos permitam compreender melhor "nuestro lugar'.

Aos pareceristas que contribuíram para que esse número fosse publicado, são eles mais de duas dezenas, nossos agradecimentos. Agradecimento estendido à Editora da UFGD, sua equipe e apoio ofertado.

Aqueles que chegaram até aqui, nossos agradecimentos. Que o conhecimento científico seja sempre aquele a descortinar o achismo e a ignorância, aquele a eliminar os 
dogmas. Que a poesia, a literatura, a arte e outras formas de expressão nos ajudem a ir além da lógica e da racionalidade formal, para com isso sermos mais humanos - inclusive para compreendermos com clareza a importância e o papel da Ciência.

Que possamos incrementar o desejo por publicar, por fazer ciência!

Uma boa leitura a todos!

Charlei Aparecido da Silva

Editor

Bruno de Souza Lima

Secretário Executivo

Rafael Brugnolli Medeiros

A Primavera está em curso,

Auxiliar Técnico

o Inverno, às vezes, dura mais que imaginamos, mas flores sempre voltam a se abrir, é uma questão de tempo... e de espaço.

Dourados (MS) - 2020 